\title{
Caladium Cultivars Cosmic Delight, Fiesta, and Hearts Desire
}

Zhanao Deng ${ }^{1}$ and Brent K. Harbaugh

Department of Environmental Horticulture, Gulf Coast Research and Education Center, Institute of Food and Agricultural Sciences, University of Florida, 14625 County Road 672, Wimauma, FL 33598

Natalia A. Peres

Department of Plant Pathology, Gulf Coast Research and Education Center, Institute of Food and Agricultural Sciences, University of Florida, 14625 County Road 672, Wimauma, FL 33598

Additional index words. Caladium $\times$ hortulanum, Caladium bicolor, Araceae, ornamental breeding

Caladiums (Caladium $\times$ hortulanum Birdsey, Araceae Juss.) are commonly grown in pots, hanging baskets, and other container types, or planted in the landscape as accent and border plants (Evans et al., 1992). They are valued for a wide array of leaf colors, coloration patterns, and shapes. The majority of commercially available caladium plants are forced from tubers. Florida growers supply the great majority of the caladium tubers used in the United States and in the world. Frequent introduction of new cultivars is important to both the Florida tuberproducing industry and landscape and greenhouse/nursery industries. New cultivars with novel or improved ornamental characteristics have been a major force attracting new interest and increased use of caladiums within all segments of these industries. For new caladium cultivars to be successfully introduced into the tuber-producing industry, adequate tuber yields with field production methods are essential.

A recent survey of the Florida caladium industry indicated that 51 caladium cultivars were planted in 2013 with two or more acres planted per cultivar (Zhanao Deng, unpublished data). These cultivars can be categorized into eight groups based on leaf type and impact leaf color [fancy white, red, pink, and novelty, and lance (or strap) white, red, pink, and novelty] (Bell et al., 1998). Various

Received for publication 2 Mar. 2016. Accepted for publication 28 Mar. 2016.

We thank the Florida Foundation Seed Procedures, Inc. and the USDA-NIFA hatch project FLA-GCR-005065 for partial funding of the development of 'Cosmic Delight', 'Hearts Desire', and 'Fiesta' caladiums. We thank Joyce Jones, Gail Bowman, Richard Kelly, Nancy West, and Teresa Seijo for their excellent technical support, Happiness Farms for evaluating 'Cosmic Delight' and 'Hearts Desire', and Bates Sons and Daughters for evaluating 'Fiesta'. The Osmocote ${ }^{\circledR}$ fertilizer used in field and greenhouse trials was donated by the Scotts Miracle-Gro Company, and the potting mix Fafard 3B was donated by Fafard, Inc. (Apopka, FL).

${ }^{1}$ Corresponding author. E-mail: zdeng@ufl.edu. subgroups may exist within major cultivar groups. White Wing and Gingerland are lance-type cultivars, falling into the lance white and the lance novelty group, respectively. They have been produced commercially for many years, and ranked third and fourth among all lance-leaved cultivars in the acreage planted (14.3 and 9.9 acres, respectively) (Deng et al., 2008). These two cultivars have not yielded well, particularly in recent years. 'White Wing' and 'Gingerland' were found to be highly susceptible to pythium root rot (Deng et al., 2005a, $2005 \mathrm{~b}$ ) and caladium growers indicated that the pythium root rot disease pressure in their fields seemed to have been increasing due to the lack of effective soil fumigants. Miss Muffet and White Queen represent two subgroups of cultivars within the fancy novelty group. Leaves of 'Miss Muffet' have a unique lemon-yellow color and many burgundy spots. Leaves of 'White Queen' are characterized by having bright red main veins and a large red area in the center. These two cultivars have been widely grown for decades, and they ranked 12th and sixth, respectively, among all fancy cultivars in acreage in 2013 (Deng et al., 2008). 'Miss Muffet' and 'White Queen' are susceptible or highly susceptible to pythium root rot (Deng et al., 2005a). Caladium growers were seeking new cultivars to complement or replace these cultivars.

The University of Florida's Institute of Food and Agricultural Sciences (UF/IFAS) initiated a caladium breeding program at the Gulf Coast Research and Education Center (GCREC; Wimauma, FL) in 1976. The main breeding objectives of this program have been to produce new caladium cultivars with novel colors, coloration patterns, increased tuber yield potentials, sunburn tolerance, and enhanced container and landscape performance. Toward these objectives, three new cultivars had been developed and they were released in 2015 to complement the abovementioned subgroups of cultivars. This report describes the origin and plant characteristics of these new cultivars and their tuber yield potential in field production and performance in container and landscape trials.

\section{Origin}

'Cosmic Delight' (Fig. 1) originated from a cross between 'Gingerland' and 'Florida Moonlight' that was made in Bradenton, FL, in 2001 (Fig. 4). Gingerland was a nonpatented commercial cultivar, whereas Florida Moonlight was a patented cultivar (U.S. Patent PP 13,135) derived from a cross between two nonpatented commercial cultivars Aaron and Candidum Jr. (Miranda and Harbaugh, 2003). 'Aaron' was developed by Frank M. Joyner in the 1950s (Bates Sons and Daughters, Inc., personal communication). The ancestries of 'Aaron', 'Gingerland', and 'Candidum Jr.' are unknown. 'Cosmic Delight' was initially selected as breeding line 75-26 in Bradenton, FL, in 2002.

'Fiesta' (Fig. 2) was progeny of a cross between 'Florida Cardinal' and 'Florida Sweetheart' made in Bradenton in Spring 2004 (Fig. 4). Florida Cardinal was a nonpatented cultivar derived from commercial cultivars Freida Hemple and Carolyn Whorton. Florida Sweetheart, resulted from a cross between Candidum Jr. and Red Frill made in Bradenton in 1977, was a patented cultivar (U.S. Patent PP 8,526), but its patent expired recently. 'Freida Hemple' was bred by Arno Nerhling in the 1910s to 1920 s, whereas 'Red Frill' was selected by Captain Webb (Bates Sons and Daughters, Inc., personal communication). The ancestries of 'Candidum Jr.', 'Carolyn Whorton', 'Freida Hemple', and 'Red Frill' are unknown. 'Fiesta' was initially selected in Wimauma in Aug. 2005.

'Hearts Desire' (Fig. 3) was derived from a cross between 'Grey Ghost' and 'Miss Muffet' that was made in Bradenton in Summer 2003 and was initially selected as breeding line 326 in Bradenton in 2004 (Fig. 4). 'Grey Ghost' was used as a parent because of its plant vigor, large tubers, and large plant and leaf size. 'Miss Muffet' was selected as a parent because of its burgundy spots and good container performance. Frank M. Joyner might be responsible for

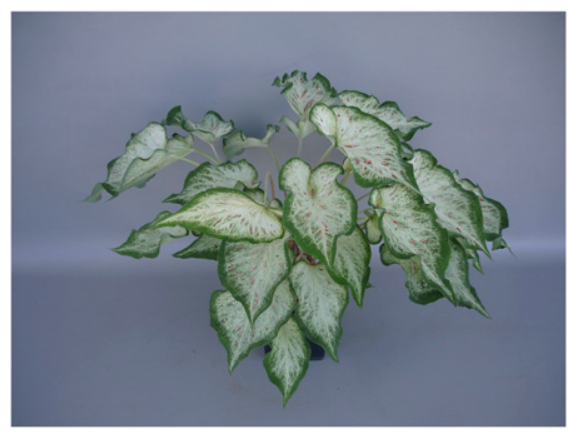

Fig. 1. A typical plant of 'Cosmic Delight' (40-d-old) forced from one No. 1-sized $(3.8$ to $6.4 \mathrm{~cm}$ diameter), de-eyed tubers in an 11.4-cm-square container. The tuber was planted on 19 May 2014, and the photo was taken on 17 June 2014. 


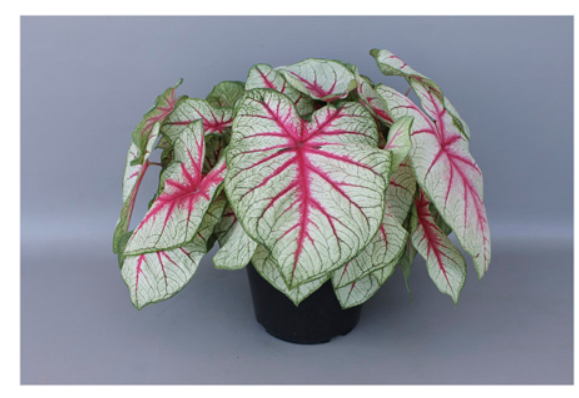

Fig. 2. A typical plant of 'Fiesta' (40-d-old) forced from four No. 1-sized (3.8 to $6.4 \mathrm{~cm}$ diameter) tubers in a $20.3-\mathrm{cm}$ container. Tubers were planted on 23 July 2014 and the photo was taken on 2 Sept. 2014

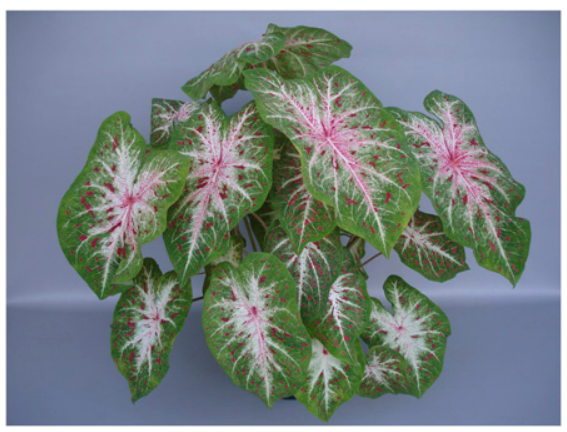

Fig. 3. A typical plant of 'Hearts Desire' (40-d-old) forced from two Jumbo-sized (6.4 to $8.9 \mathrm{~cm}$ diameter), de-eyed tubers in a $20.3-\mathrm{cm}$ container. Tubers were planted 19 May 2014 and the photo was taken on 27 June 2014.

developing 'Miss Muffet' (Bates Sons and Daughters, Inc., personal communication). Information about the parentage of 'Grey Ghost' and 'Miss Muffet' is not available.

'Cosmic Delight', 'Fiesta', and 'Hearts Desire' have been asexually propagated through tuber division for nine generations or more in Wimauma and/or Lake Placid. Their plant, foliar, and growth characteristics were stable and consistent during asexual propagation.

\section{Description}

Description of color (e.g., RHS 200B) for plant parts were based on comparison with the Royal Horticultural Society Color Chart (Royal Horticultural Society, 1986). Plants used for color description were grown from de-eyed, Jumbo-sized (or equivalent) tubers (two per container) in 20.3-cm containers in a shaded greenhouse with $\approx 30 \%$ light exclusion. The containers were filled with the potting mix Fafard 3B (Conrad Fafard Inc., Agawam, MA) amended with the commercial controlled-release fertilizer Osmocote ${ }^{\circledR}$ (15N-3.9P-10K, 5-6 months; Scotts Co., Marysville, $\mathrm{OH}$ ) at the rate of $4.3 \mathrm{~kg} \cdot \mathrm{m}^{-3}$.

'Cosmic Delight'. Plants are $\approx 40 \mathrm{~cm}$ tall and $78 \mathrm{~cm}$ wide and produce upright, outwardly arching leaves. Mature leaves have an average size of $25 \mathrm{~cm}$ (length) $\times 16.5 \mathrm{~cm}$ (width). Leaves are sagittate-cordate, 21$29 \mathrm{~cm}$ long and $13-20 \mathrm{~cm}$ wide, and slightly undulate with white (RHS 155D) penniform venation. The upper surface has green (RHS 139A) margins, up to $10 \mathrm{~mm}$ wide, bordering the entire leaf except for the basal leaf valley formed by the two lobes where there is a 1- to 2-mm-wide greyed-purple (RHS 185B) band. The central and main veins are white (RHS 157C). Interveinal areas are white (RHS 155B) except for the areas near the margins where irregular greyed-green (RHS 190D) mottling and blotching of green (RHS 139A) is present. Spots of light red purple (RHS 63A or $63 \mathrm{D})$ are distributed throughout the leaf surface. The abaxial surface has greyedgreen (RHS 191A) margins, up to $10 \mathrm{~mm}$ wide, and a white (RHS 155D) center and greyed-green (RHS 193D) central and main veins. Secondary veins are greyed green (RHS 191C) and netted. Blotches of greyed purple (RHS $186 \mathrm{D}$ to $186 \mathrm{D}$ ) appear toward the margins. Petioles are $3.5-5.1 \mathrm{~mm}$ and green (RHS 142D) at the apex, but the color diffuses into greyed purple (RHS 184B) with blotching of brown (RHS 200B) near the base, which is $7.1-10.4 \mathrm{~mm}$ in diameter. Jumbo-sized tubers are multisegmented, bearing five to nine dominant buds. Tuber surfaces are brown (RHS 200B), with the cortical area being yellow orange (RHS 4C).

'Fiesta'. Plants are $\approx 23 \mathrm{~cm}$ tall and $45 \mathrm{~cm}$ wide and produce multiple leaves cascading from the center. Mature leaves have an average length of $20 \mathrm{~cm}$ and width of $15 \mathrm{~cm}$. Leaves are peltate, sagittate-cordate, with palmate-pinnate venation. The upper leaf surface is white (RHS 155B), with narrow green (RHS 137A) margins bordering the entire leaf except for the basal leaf valley where it is red (RHS 53A) and a basal notch of greyed purple (RHS 187B). Primary veins are greyed purple (RHS 183C) near the center and change into green (RHS 137A) toward the margins. Netted secondary veins occur on $50 \%$ to $80 \%$ of the leaf surface and are green (RHS 137A). Bands of red (RHS 53C) bleed along primary and secondary veins. The abaxial surface has greyed-green (RHS 191A) margins with blotches of yellow white (RHS 158A) and bleeding of greyed purple (RHS 185C) around the veins. Mid veins are yellow white (RHS 158D), and primary veins are greyed green (RHS 189A). Petioles of mature leaves are $3.2-4.1 \mathrm{~mm}$ in diameter and generally greyed orange (RHS 164D) with long streaks or blotches of greyed orange (RHS 165A). Immature petioles may be yellow green (RHS 149D). Jumbo tubers are multisegmented, bearing three to five dominant buds. Tuber surfaces are brown (RHS 200C) with the tuber cortical area in yellow (RHS 4B).

'Hearts Desire'. Plants are $\approx 52 \mathrm{~cm}$ tall and $76 \mathrm{~cm}$ wide and have upright, outwardly arching leaves. Mature leaves have an average size of $31 \mathrm{~cm}$ (length) $\times 19.5 \mathrm{~cm}$ (width). Leaves are peltate, sagittate-cordate, with green-white (RHS 157B) palmate-pinnate venation. The upper surface is green (RHS 139C) with bleeding of white (RHS 155B) radiating from the mid and primary veins. Interveinal areas are green white (RHS 157B) near the central main vein and change to green (RHS 138A) near the margin. Numerous variable-sized blotches of greyed purple (RHS 185B) are scattered along with netted green (RHS 138A) veins. The abaxial surface is greyed green (RHS 191B). Mid and primary veins are green (RHS 157C), with some bleeding of white (RHS 155B) surrounding them. Greyed-purple spots (RHS 185B) are numerous and scattered between primary veins. Petioles are $4.4-6.3 \mathrm{~mm}$ in diameter and green (RHS 142D), with green (RHS 143C) blotches or streaks near the base, which is $\approx 8.5-11.2 \mathrm{~mm}$ in diameter. Tuber surfaces are brown (RHS 200C), with the cortical area in yellow (RHS 13B).

\section{Tuber Yield Potential}

Field experiments. 'Cosmic Delight', 'Hearts Desire', and 'Fiesta' were evaluated for tuber production and plant performance at the GCREC in 2007, 2009, and/or 2014. The soil was EauGallie fine sand with $\approx 1 \%$ organic matter and a $\mathrm{pH}$ between 6.2 and 7.4. Caladium plants were grown in the field using a plastic-mulched raised-bed system. For the 2007 evaluation, ground beds $(81 \mathrm{~cm}$ wide, $20 \mathrm{~cm}$ high) were fumigated on $3 \mathrm{Apr}$. with a mixture of $67 \%$ methyl bromide and $33 \%$ chloropicrin (by volume) at $196 \mathrm{~kg} \cdot \mathrm{ha}^{-1}$. Caladium seed pieces (tuber pieces, $\approx 2.5 \times$ $2.5 \times 2.5 \mathrm{~cm}$ ) were planted manually on 26 Apr. with $\approx 25.4 \mathrm{~cm}$ between-row spacing and $\approx 15.2 \mathrm{~cm}$ in-row spacing. Drip tapes were buried under the plastic mulch and delivered $\approx 6 \mathrm{~mm}$ of water to the bed per day. Fertigation began when young caladium plants emerged from the soil, supplying soluble fertilizer $(6 \mathrm{~N}-0.8 \mathrm{P}-3.9 \mathrm{~K})$ at the rate of $\approx 1.9 \mathrm{~kg} \cdot \mathrm{ha}^{-1} \cdot \mathrm{d}^{-1}$ of nitrogen and a total 290 $\mathrm{kg} \cdot \mathrm{ha}^{-1}$ of nitrogen per growing season. New crop tubers were dug, washed, and dried in early Jan. 2008. Dried tubers from each experimental field plot were weighed, graded, and counted in late Jan. 2008, as described by Deng and Harbaugh (2006). Tuber grading was by the maximum diameter: No. 2 (2.5 to $3.8 \mathrm{~cm})$, No. 1 (3.8 to 6.4 $\mathrm{cm})$, Jumbo (6.4 to $8.9 \mathrm{~cm})$, Mammoth ( 8.9 to $11.4 \mathrm{~cm}$ ), and Super Mammoth (greater than $11.4 \mathrm{~cm}$ ). Tuber grades and counts were converted into a production index (PI) to show the relative economic value of the harvested tubers per field plot: $\mathrm{PI}=\mathrm{N}$ (No. $2)+2 \mathrm{~N}($ No. 1$)+4 \mathrm{~N}$ (Jumbo) $+6 \mathrm{~N}$ (Mammoth) $+8 \mathrm{~N}$ (Super Mammoth), where $\mathrm{N}$ is number of tubers in the grade. The relative values assigned to the five tuber grades in calculating PIs were based on the relative market prices provided by Florida caladium tuber producers.

For the 2009 evaluation, beds were fumigated on $27 \mathrm{Feb}$. with a mixture of $50 \%$ methyl bromide and $50 \%$ chloropicrin (by volume) at $196 \mathrm{~kg} \cdot \mathrm{ha}^{-1}$. Caladium seed pieces were planted on 9 Apr. at $\approx 15 \mathrm{~cm}$ spacing between rows and in rows. The irrigation and fertigation system was the same as the one 

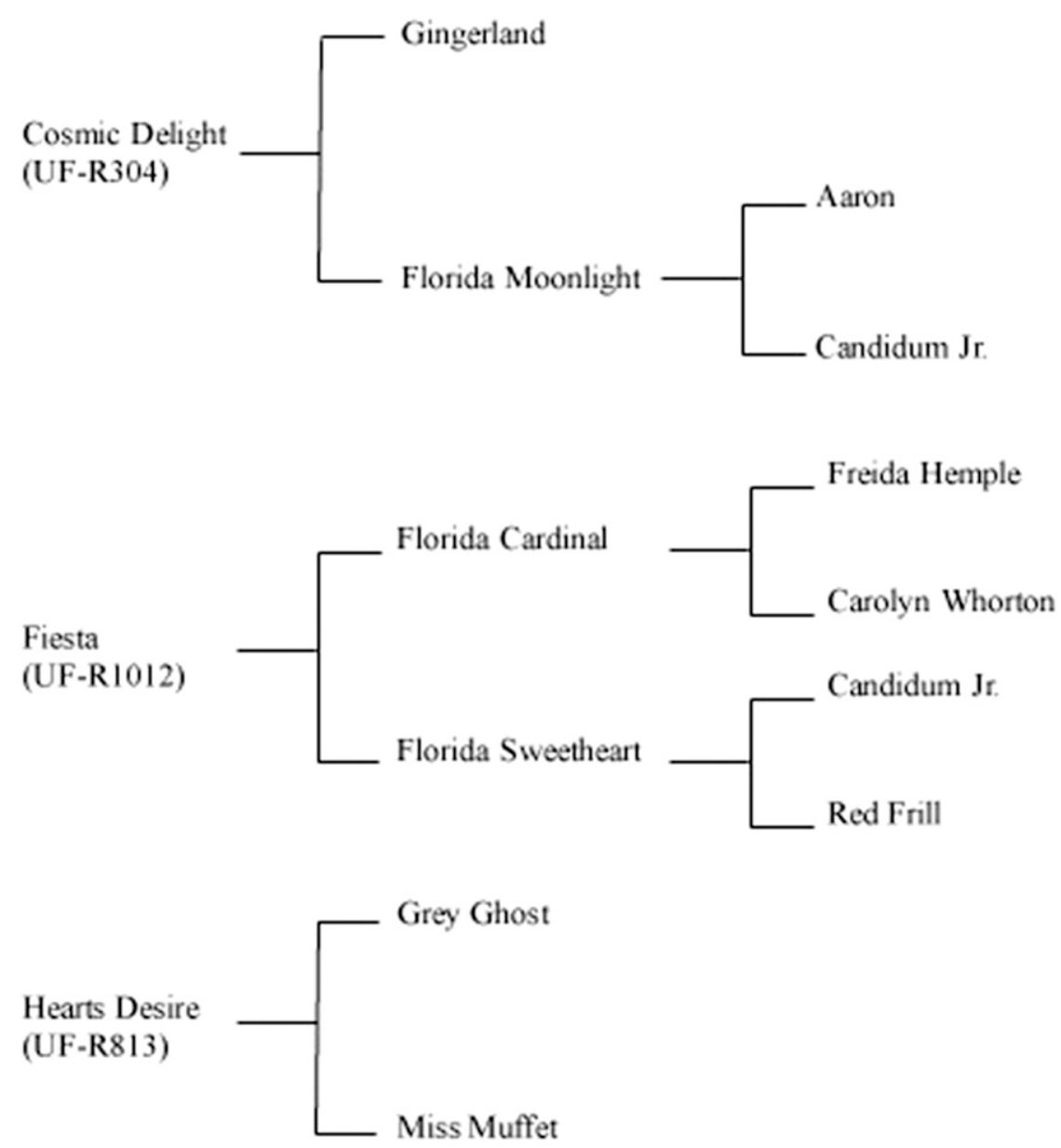

Fig. 4. Pedigree of 'Cosmic Delight', 'Fiesta', and 'Hearts Desire' caladium. In the parentheses are the names under which these cultivars were released.

used in 2007 , but one teaspoon $(\approx 7 \mathrm{~g})$ of the controlled-release fertilizer Osmocote $^{\circledR}(15 \mathrm{~N}-2.6 \mathrm{P}-10 \mathrm{~K}, 5-6$ months $)$ was applied to each plant on 21 July. Tubers were dug from 30 Nov. to 2 Dec. 2009, followed by the washing, drying, weighing, grading, and counting procedures as were done in 2007.

For the 2014 evaluation, beds were fumigated on 9 Jan. with Pic-Clor $60^{\circledR}(39.0 \%$ 1,3-dichloropropene and $59.6 \%$ chloropicrin) at $448 \mathrm{~kg} \cdot \mathrm{ha}^{-1}$ of Plantacote ${ }^{\circledR}$ Pluss, a controlled-release fertilizer $(14 \mathrm{~N}-3.9 \mathrm{P}-$ $12.5 \mathrm{~K}, 12$ months; X-Calibur Plant Health Company, LLC, Summervile, SC), was incorporated into the bed at $336 \mathrm{~kg} \cdot \mathrm{ha}^{-1}$. Caladium seed pieces were planted on 16 and 28 Apr. at $\approx 15 \mathrm{~cm}$ spacing between rows and in rows. Irrigation was by seepage as described by Geraldson et al. (1965). Caladium plants were fertilized with 600 ppm of $\mathrm{N}$ with a commercial water-soluble fertilizer (20N-8.7P-16.6K; Southern Agricultural Insecticides, Inc., Palmetto, FL) on 18 Sept. and 1 Oct. 2014. Tubers were dug from 1 to 9 Dec. 2014, followed by the same washing, drying, weighing, grading, and counting procedures as were done in 2007.

In each year, field plots were arranged in a randomized complete block design with three replicates. Each plot was $1.2 \mathrm{~m}^{2}$ and was planted with 30 caladium propagules (tuber pieces). Major commercial cultivars with similar coloration patterns were planted in the field as controls to assess the tuber yield and plant performance of Cosmic Delight, Hearts Desire, and Fiesta. The controls used were 'White Wing', 'Gingerland', and 'Florida White Ruffles' (2007 only) for 'Cosmic Delight', 'Miss Muffet' for 'Hearts Desire', and 'White Queen' and 'Florida Fantasy' for 'Fiesta'. Florida White Ruffles is a lanceleaved white cultivar that was developed and released by the UF/IFAS caladium breeding program more than 10 years ago (Baldwin et al., 2002). Analysis of variance was conducted using the GLM procedure in the SAS program, followed by mean comparisons by Fisher's least square difference (SAS Institute, 2010).

'Cosmic Delight'. The tuber weight and PI of this cultivar were significantly greater than those of 'Florida White Ruffles', 'White Wing', and 'Gingerland' in both 2007 and 2014 (Table 1). The tuber weight of 'Cosmic Delight' was $65 \%$ to $578 \%$ greater than the tuber weight of the three controls in 2007 and $125 \%$ to $246 \%$ greater in 2014 (Table 1). The PI of 'Cosmic Delight' was $62 \%$ to $259 \%$ greater than that of the controls in 2007 and $91 \%$ to $183 \%$ greater in 2014 (Table 1). Plants of 'Cosmic Delight' produced 56\% to $66 \%$ more marketable tubers than the plants of the controls in 2007 and $23 \%$ or $37 \%$ more marketable tubers than the controls in 2014 (Table 1). Plants of 'Cosmic Delight' produced more Mammoth- and Jumbo-grade tubers than plants of 'White Wing' in 2007 and in 2014 (Table 1). Plants of 'Cosmic Delight' yielded more Mammoth- and Jumbo-grade tubers than plants of 'Gingerland' in 2014, but not in 2007. Overall, data from both 2007 and 2014 growing seasons showed that 'Cosmic Delight' had much higher tuber yields than 'Gingerland', 'Florida White Ruffles', and 'White Wing'.

'Fiesta'. This cultivar was not significantly different from 'Florida Fantasy' or 'White Queen' in tuber weight, number of marketable tubers, and PI in 2007 and 2009. The tuber size distribution of 'Fiesta', 'Florida Fantasy', and 'White Queen' was also not significantly different, except that 'Florida Fantasy' produced more No. 1-grade tubers than 'Fiesta'.

'Hearts Desire'. There were no significant differences between this cultivar and the control 'Miss Muffet' in tuber weight, number of marketable tubers, and PI in 2014 in both growing seasons (Table 1). Overall, 'Hearts Desire' and 'Miss Muffet' showed similar tuber size distributions, except that 'Hearts Desire' produced fewer No. 1-grade tubers in 2009 (Table 1).

\section{Pot Trials}

The suitability of 'Cosmic Delight' and 'Hearts Desire' for pot plant production was evaluated by forcing tubers in $11.4-\mathrm{cm}$ containers (diameter) in Spring/Summer 2014. No. 1 tubers were planted on 24 Apr. in a commercial potting mix (Fafard 3B) amended with Osmocote ${ }^{\circledR}$ controlledrelease fertilizer $(15 \mathrm{~N}-3.9 \mathrm{P}-10 \mathrm{~K}, 5-6$ months $)$ at $4.3 \mathrm{~kg} \cdot \mathrm{m}^{-3}$; plants were grown in a greenhouse with $\approx 30 \%$ light exclusion. Temperatures in the greenhouse ranged from $16^{\circ} \mathrm{C}$ at night to $30{ }^{\circ} \mathrm{C}$ during the day. Potted plants were arranged on metal benches in the greenhouse in a randomized complete block design with six replicates. Plant height, plant width, number of leaves, and foliar characteristics were recorded on 19-20 June 2014, 8 weeks after planting. Quality of the potted caladium plants was rated on a scale of 1 to 5 , with $1=$ very poor, unattractive, totally unacceptable as potted plants with few leaves, and $5=$ very attractive, full plants with a symmetrical shape, an appropriate height, and many bright, colorful leaves. The suitability of 'Fiesta' for pot plant production was evaluated in Spring 2008. No. 1 tubers were planted in 11.4- $\mathrm{cm}$ containers filled with a peat/vermiculite mix (VerGro Container Mix A; Verlite, Tampa, FL) on 17 Apr. 2008. The greenhouse was covered with an aluminum net that provided $\approx 45 \%$ light exclusion. Temperatures in the greenhouse ranged from $16{ }^{\circ} \mathrm{C}$ at night to $29^{\circ} \mathrm{C}$ during the day. Potted plants were arranged on metal benches in the greenhouse in a randomized 
complete block design with eight replicates. Plant height, plant width, number of leaves, and foliar characteristics were recorded on 12 June 2008, 8 weeks after planting.

'Cosmic Delight'. Intact tubers sprouted $25 \mathrm{~d}$ after planting, $\approx 5 \mathrm{~d}$ earlier than those of 'White Wing' (Table 2). Plants from the intact tubers were similar to plants of "White Wing', having similar plant heights, similar numbers of leaves, similar leaf lengths, and similar plant quality ratings, except that the leaves of 'Cosmic Delight' were $4.1 \mathrm{~cm}$ wider leaves than those of 'White Wing' (Table 2). When tubers were planted intact, 'Cosmic Delight' and 'Gingerland' were similar in sprouting time, plant height, numbers of leaves, and leaf width, and received similar plant quality ratings. The exception was that leaves of 'Cosmic Delight' were $2.2 \mathrm{~cm}$ longer than those of 'Gingerland'.
De-eyed tubers of 'Cosmic Delight' sprouted in $24 \mathrm{~d}$ after planting, similar to the de-eyed tubers of 'White Wing' and 'Gingerland' (Table 2). There were no significant differences among plants of 'Cosmic Delight', 'White Wing', and 'Gingerland' forced from de-eyed tubers in plant height, numbers of leaves, and leaf length. However, plants of 'Cosmic Delight' had wider leaves than plants of 'White Wing' (10.9 vs. $8.1 \mathrm{~cm})$ and received a lower plant quality rating than plants of 'Gingerland' (3.9 vs. 4.4).

'Cosmic Delight' produced marketable pot plants without tuber de-eyeing. However, de-eyeing resulted in pot plants with improved quality (Table 2). Plants of 'Cosmic Delight' from de-eyed tubers had $91 \%$ more but smaller ( $22 \%$ shorter and $31 \%$ narrower) leaves, and received a higher quality rating (3.9 vs. 3.0) than plants from intact tubers.
'Fiesta'. This cultivar was quick to sprout regardless of tuber treatments. Intact and deeyed tubers sprouted 22 and $23 \mathrm{~d}$ after planting, 7 to $13 \mathrm{~d}$ earlier than 'Florida Fantasy' and 'White Quite' (Table 2). Plants of 'Fiesta' were similar to 'Florida Fantasy' in plant height, but significantly shorter than 'White Queen' (Table 2).

Plants of 'Fiesta' had 84\% (intact tubers) and $188 \%$ (de-eyed tubers) more leaves than those of 'White Queen' (Table 2). Leaves of 'Fiesta' and 'White Queen' plants from intact tubers were similar in length and width, whereas leaves of 'Fiesta' plants from de-eyed tubers were shorter and narrower than those of 'White Queen' plants from de-eyed tubers. Plants of 'Fiesta' received a quality rating of 2.4 and 4.0 for intact and de-eyed tubers, respectively, both were significantly higher than the quality rating of 'White Queen' plants.

Table 1. Weight, production index (PI), marketable number, and grade distribution of tubers produced by caladium cultivars in experimental field plots (2007, 2009 , and/or 2014). Values presented are means of three replications with 30 propagules planted in a plot $\left(1.2 \mathrm{~m}^{2}\right)$ each year.

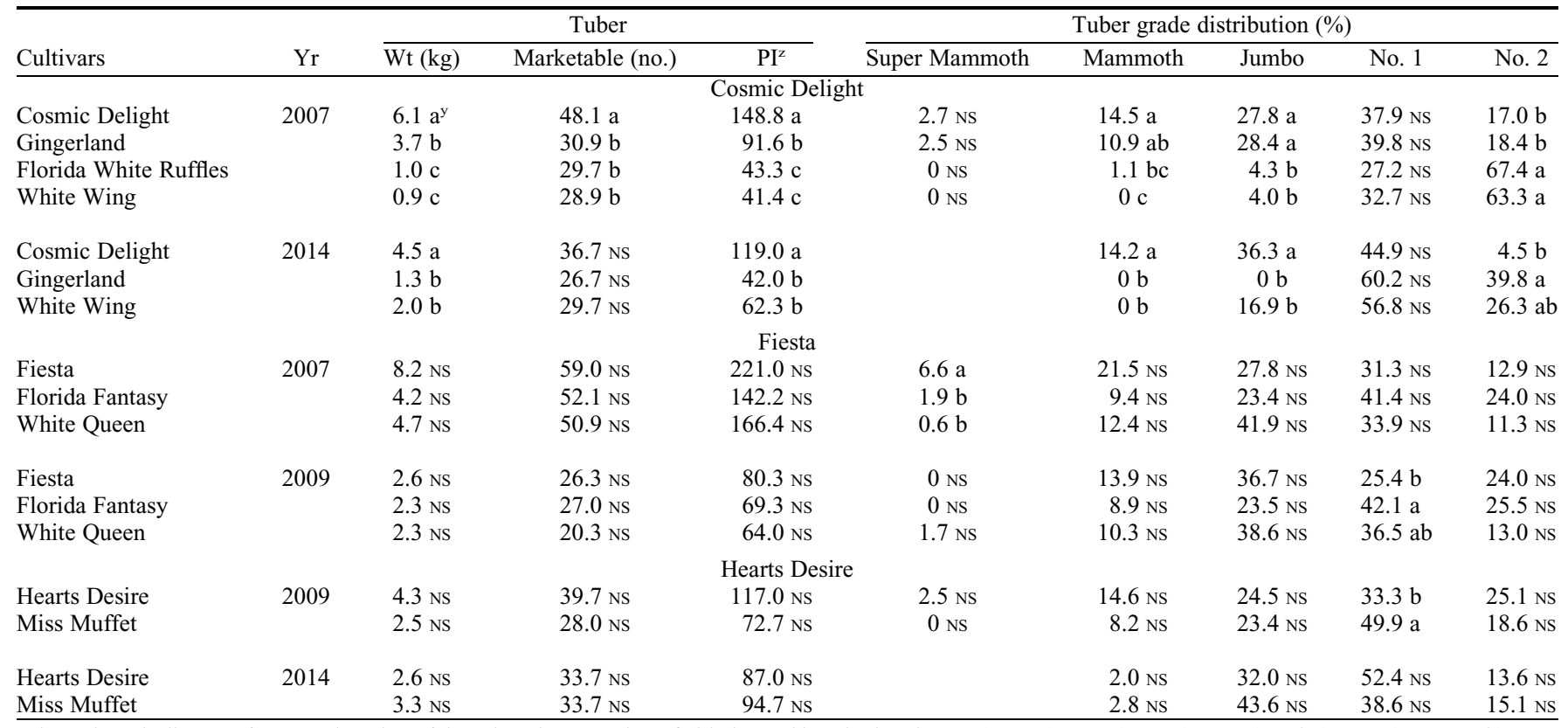

${ }^{2}$ The PI is an indicator of economic value of the tubers harvested per field plot and is calculated as: $\mathrm{N}(\mathrm{No} .2 \mathrm{~s})+2 \mathrm{~N}(\mathrm{No} .1 \mathrm{~s})+4 \mathrm{~N}(\mathrm{Jumbo})+6 \mathrm{~N}(\mathrm{Mammoth})+8 \mathrm{~N}$ (Super Mammoth), where $\mathrm{N}=$ number of tubers in each grade. Tubers graded by maximum diameter; No. 2 (2.5 to $3.8 \mathrm{~cm})$, No. 1 ( 3.8 to $6.4 \mathrm{~cm})$, Jumbo (6.4 to 8.9 $\mathrm{cm})$, Mammoth $(8.9$ to $11.4 \mathrm{~cm})$, and Super Mammoth $(>11.4 \mathrm{~cm})$.

${ }^{y}$ Mean values with the same letters within columns and groups are not significantly different at $P \leq 0.05$.

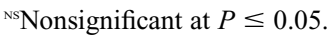

Table 2. Days to sprout, plant height, leaf number, leaf size, and plant quality of caladiums grown from No. 1 tubers in 11.4-cm containers in a shaded glasshouse in Wimauma, FL (2008 or 2014). Values represent the means of eight or six plants produced from intact or de-eyed No. $1(3.8$ to $6.4 \mathrm{~cm}$ in diameter) tubers planted individually per container.

\begin{tabular}{|c|c|c|c|c|c|c|c|c|c|c|c|c|}
\hline \multirow[b]{2}{*}{ Cultivars } & \multicolumn{2}{|c|}{ Days to sprout ${ }^{z}$} & \multicolumn{2}{|c|}{ Plant ht $(\mathrm{cm})$} & \multicolumn{2}{|c|}{ Leaves (no.) } & \multicolumn{2}{|c|}{ Leaf length $(\mathrm{cm})$} & \multicolumn{2}{|c|}{ Leaf width $(\mathrm{cm})$} & \multicolumn{2}{|c|}{ Quality rating } \\
\hline & Intact & $\overline{\text { De-eyed }}$ & Intact & $\overline{\text { De-eyed }}$ & Intact & $\overline{\text { De-eyed }}$ & Intact & $\overline{\text { De-eyed }}$ & Intact & $\overline{\text { De-eyed }}$ & Intact & De-eyed \\
\hline Gingerland & $21 \mathrm{~b}$ & $25 \mathrm{NS}$ & $30.5 \mathrm{a}$ & $29.3 \mathrm{NS}$ & $11.0 \mathrm{NS}$ & $30.2 \mathrm{a}$ & $21.3 \mathrm{~b}$ & $16.1 \mathrm{NS}$ & $15.1 \mathrm{a}$ & $9.6 \mathrm{ab}$ & $3.0 \mathrm{NS}$ & $4.4 \mathrm{a}$ \\
\hline Fiesta & $22 \mathrm{~b}$ & $23 \mathrm{~b}$ & $20.3 \mathrm{~b}$ & $18.6 \mathrm{~b}$ & $14.9 \mathrm{a}$ & $32.8 \mathrm{a}$ & $27.1 \mathrm{ab}$ & $20.3 \mathrm{~b}$ & $21.7 \mathrm{a}$ & $14.6 \mathrm{~b}$ & $2.4 \mathrm{~b}$ & $4.0 \mathrm{a}$ \\
\hline Florida Fantasy & $35 \mathrm{a}$ & $30 \mathrm{a}$ & $22.9 \mathrm{~b}$ & $21.5 \mathrm{~b}$ & $14.4 \mathrm{a}$ & $20.6 \mathrm{~b}$ & $24.8 \mathrm{~b}$ & $23.0 \mathrm{a}$ & $17.7 \mathrm{~b}$ & $16.3 \mathrm{ab}$ & $3.0 \mathrm{a}$ & $3.7 \mathrm{a}$ \\
\hline White Queen & $34 \mathrm{a}$ & $30 \mathrm{a}$ & $32.0 \mathrm{a}$ & $29.1 \mathrm{a}$ & $8.1 \mathrm{~b}$ & $11.4 \mathrm{c}$ & $29.4 \mathrm{a}$ & $23.6 \mathrm{a}$ & $21.9 \mathrm{a}$ & $18.1 \mathrm{a}$ & $1.9 \mathrm{c}$ & $2.8 \mathrm{~b}$ \\
\hline Miss Muffet & $18 \mathrm{a}$ & $24 \mathrm{NS}$ & $26.3 \mathrm{~b}$ & $26.2 \mathrm{~b}$ & $15.2 \mathrm{NS}$ & $33.3 \mathrm{NS}$ & $24.0 \mathrm{~b}$ & $17.4 \mathrm{NS}$ & $15.6 \mathrm{~b}$ & $11.2 \mathrm{~b}$ & $3.5 \mathrm{NS}$ & $4.5 \mathrm{NS}$ \\
\hline
\end{tabular}

${ }^{2}$ Number of days from planting to the first unfurled leaf.

${ }^{y}$ Mean separation within column and group for each cultivar by Fisher's least significant difference test at $P \leq 0.05$.

${ }^{\text {ss }}$ Nonsignificant at $P \leq 0.05$. 
Plants of 'Fiesta' from intact tubers had similar numbers of leaves and leaf lengths with plants of 'Florida Fantasy', but a greater leaf width and a lower quality rating than plants of 'Florida Fantasy'. However, plants of 'Fiesta' from de-eyed tubers had 59\% more leaves, and leaves were $2.7 \mathrm{~cm}$ shorter and $1.7 \mathrm{~cm}$ narrower than the leaves of 'Florida Fantasy' from de-eyed tubers. Plant quality ratings of 'Fiesta' and 'Florida Fantasy' were comparable when tubers were deeyed before planting.

'Hearts Desire'. Tubers of this cultivar were sprouted in $16 \mathrm{~d}$ for intact tubers and in $24 \mathrm{~d}$ for de-eyed tubers, $2 \mathrm{~d}$ earlier than or similar to the sprouting time of 'Miss Muffet' (Table 2). Plants of 'Hearts Desire' from intact tubers were $51 \%$ taller than plants of 'Miss Muffet' (39.6 vs. $26.3 \mathrm{~cm}$ ), and the leaves of 'Hearts Desire' were $25 \%$ longer and $26 \%$ wider than the leaves of 'Miss Muffet'. Plants of 'Hearts Desire' from intact tubers received a similar quality rating as plants of 'Miss Muffet' from intact tubers. Plants of 'Hearts Desire' grown from de-eyed tubers were $51 \%$ taller than those of 'Miss Muffet', but had a similar number of leaves. Leaves of 'Hearts Desire' plants were similar to those of 'Miss Muffet' in length but $2.4 \mathrm{~cm}$ wider. Plants of 'Hearts Desire' forced from de-eyed tubers received a plant quality rating of 4.0, similar to the plant quality rating of 'Miss Muffet' (4.5).

\section{Landscape Performance}

Landscape performance was evaluated using the same plantings for evaluating tuber yield potential. A scale of 1 to 5 was used with 1 being very poor (few leaves and lack of vigor), and 5 being excellent (full plants, numerous leaves, and bright color display). Leaf sun tolerance was evaluated on a scale of 1 to 5 , with 1 being very susceptible to sunburn (leaves having numerous sundamaged areas or holes) and 5 being resistant to sunburn (no visible sun-damaged areas). Three to four evaluations were conducted in each growing season for plant performance and sunburn tolerance. Evaluations were done in July, Aug., and Sept. 2007; Aug., Sept., and Oct. 2009; and/or Aug., Sept., and Oct. 2014. Plant height, number of leaves per plant, and leaf size (length and width) were measured on three plants arbitrarily chosen from each plot, $\approx 4$ months after planting.

'Cosmic Delight'. Plants were 10.6 and $13.7 \mathrm{~cm}$ taller than those of 'Gingerland' and 'White Wing', respectively (Table 3). Plants of 'Cosmic Delight' had an average of 22.8 leaves per plant, which was $95 \%$ and $107 \%$ more than 'Gingerland' and 'White Wing', respectively. Leaves of 'Cosmic Delight' were significantly longer than the leaves of 'Gingerland' and 'White Wing', and also significantly wider than leaves of 'White Wing'.
Plants of 'Cosmic Delight' performed well in both 2007 and 2014 growing seasons, with performance ratings between 4.0 and 5.0, which were significantly higher than those of 'Gingerland', 'White Ruffles', and 'White Wing' in all three evaluations in 2007, and also significantly higher than those of 'Gingerland' and 'White Wing' in two or three of four evaluations in 2014 (Table 4). Plants of 'Cosmic Delight' showed good to excellent sunburn tolerance in both 2007 and 2014 growing seasons, with sunburn tolerance ratings between 3.7 and 4.8 (Table 5). Its sunburn tolerance ratings were significantly higher than those of 'Gingerland' in four of seven evaluations, better than those of 'Florida White Ruffles' in two of three evaluations, and higher than those of 'White Wing' in two of seven evaluations.

'Fiesta'. Plants of 'Fiesta' and 'Florida Fantasy' were not significantly different in plant height and number of leaves (Table 3 ). Their leaves were not significantly different in width, but had different lengths $(22.4 \mathrm{~cm}$ vs. $28.7 \mathrm{~cm}$, respectively). Compared with 'White Queen', plants of 'Fiesta' had 63\% more leaves and leaves were $6.5 \mathrm{~cm}$ shorter. Plants of 'Fiesta', 'Florida Fantasy', and 'White Queen' performed similarly in both 2007 and 2009 growing seasons, with similar performance ratings in two of the three evaluations in 2007 and in all three evaluations in 2009 (Table 4). In one evaluation

Table 3. Characteristics of caladium plants grown from tuber propagules $(\approx 2.54 \mathrm{~cm})$ in ground beds in full sun in Wimauma, FL (2007, 2009, and/or 2014$)$. Values presented for plant height and leaf number, length, and width were means of three replications with three plants measured per plot per year and averaged over 2 years.

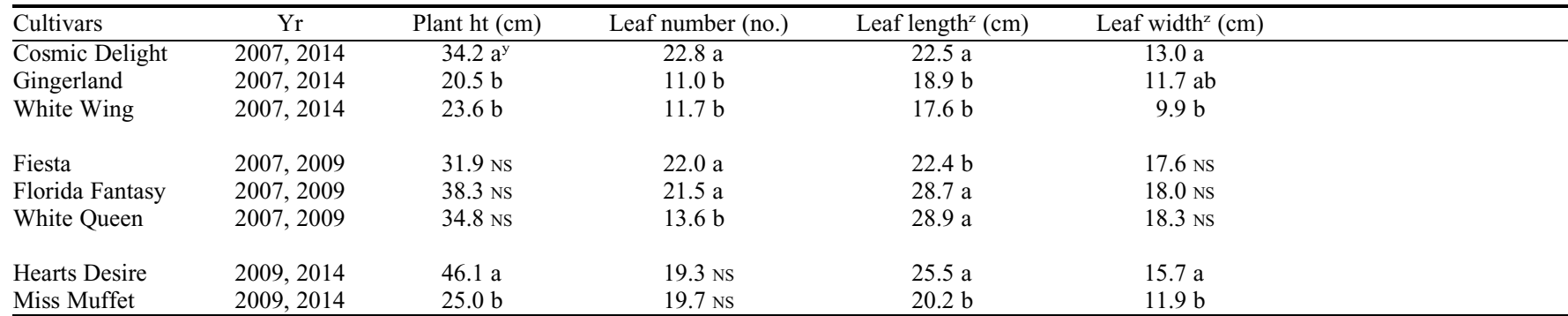

${ }^{\mathrm{z}}$ Leaf length and width were measured on the largest leaves along the longest line from the leaf lobe to the leaf tip and across the widest middle part, respectively. ${ }^{y}$ Mean separation within columns and groups by Fisher's least significant difference test at $P \leq 0.05$.

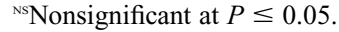

Table 4. Plant performance ratings of caladiums grown from 2.54-cm tuber propagules in ground beds in full sun in Wimauma, FL (2007, 2009, and/or 2014). Performance ratings are means of three replications based on whole plot evaluation in each evaluation.

\begin{tabular}{|c|c|c|c|c|c|c|c|c|c|c|}
\hline \multirow[b]{2}{*}{ Cultivars } & \multicolumn{10}{|c|}{ Plant performance rating ${ }^{z}$} \\
\hline & July 2007 & Aug.t 2007 & Sept. 2007 & Aug. 2009 & Sept. 2009 & Oct. 2009 & July 2014 & Aug. 2014 & Sept. 2014 & Oct. 2014 \\
\hline Cosmic Delight & $4.0 \mathrm{a}^{\mathrm{y}}$ & $4.2 \mathrm{a}$ & $4.9 \mathrm{a}$ & $-{ }^{x}$ & - & - & $4.0 \mathrm{NS}$ & $4.1 \mathrm{a}$ & $4.3 \mathrm{a}$ & $5.0 \mathrm{a}$ \\
\hline Gingerland & $1.8 \mathrm{~b}$ & $1.7 \mathrm{~b}$ & $2.8 \mathrm{~b}$ & - & - & - & $3.2 \mathrm{NS}$ & $2.9 \mathrm{~b}$ & $2.7 \mathrm{~b}$ & $2.3 \mathrm{c}$ \\
\hline Florida White Ruffles & $2.2 \mathrm{~b}$ & $1.8 \mathrm{~b}$ & $2.2 \mathrm{c}$ & - & - & - & - & - & - & - \\
\hline White Wing & $2.6 \mathrm{~b}$ & $2.2 \mathrm{~b}$ & $2.0 \mathrm{c}$ & - & - & - & $3.2 \mathrm{NS}$ & $3.4 \mathrm{~b}$ & $3.3 \mathrm{ab}$ & $3.2 \mathrm{~b}$ \\
\hline Fiesta & $4.1 \mathrm{a}$ & $3.3 \mathrm{NS}$ & $2.7 \mathrm{NS}$ & $3.2 \mathrm{NS}$ & $4.3 \mathrm{NS}$ & $4.2 \mathrm{NS}$ & - & - & - & - \\
\hline Florida Fantasy & $2.9 \mathrm{~b}$ & $3.4 \mathrm{NS}$ & $3.1 \mathrm{NS}$ & $3.7 \mathrm{NS}$ & $4.3 \mathrm{NS}$ & $4.2 \mathrm{NS}$ & - & - & - & - \\
\hline White Queen & $3.3 \mathrm{ab}$ & $3.5 \mathrm{NS}$ & $3.6 \mathrm{NS}$ & $3.2 \mathrm{NS}$ & $3.8 \mathrm{NS}$ & $3.8 \mathrm{NS}$ & - & - & - & - \\
\hline Hearts Desire & - & - & - & $4.8 \mathrm{a}$ & $3.8 \mathrm{NS}$ & $4.0 \mathrm{NS}$ & $4.4 \mathrm{NS}$ & $4.4 \mathrm{NS}$ & $3.7 \mathrm{NS}$ & $4.0 \mathrm{a}$ \\
\hline Miss Muffet & - & - & - & $3.7 \mathrm{~b}$ & $3.8 \mathrm{NS}$ & $3.8 \mathrm{NS}$ & $3.4 \mathrm{NS}$ & $4.4 \mathrm{NS}$ & $4.0 \mathrm{NS}$ & $3.4 \mathrm{~b}$ \\
\hline
\end{tabular}

zPlants were rated on a scale of 1 to 5 , with 1 being very poor, 3 fair and acceptable, and 5 being excellent in plant vigor, fullness, and color display.

${ }^{\mathrm{y}}$ Mean separation within columns and groups by Fisher's least significant difference test at $P \leq 0.05$.

xPlants were not evaluated and data were unavailable.

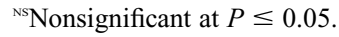


Table 5. Sunburn tolerance of caladium plants grown from 2.54-cm tuber propagules in ground beds in full sun in Wimauma, FL (2007, 2009, and/or 2014). Sunburn tolerance ratings are means of three replications based on whole plot evaluation in each evaluation.

\begin{tabular}{|c|c|c|c|c|c|c|c|c|c|c|}
\hline \multirow[b]{2}{*}{ Cultivars } & \multicolumn{10}{|c|}{ Sunburn tolerance rating ${ }^{z}$} \\
\hline & July 2007 & Aug. 2007 & Sept. 2007 & Aug. 2009 & Sept. 2009 & Oct. 2009 & July 2014 & Aug. 2014 & Sept. 2014 & Oct. 2014 \\
\hline Gingerland & $3.0 \mathrm{~b}$ & $4.6 \mathrm{~b}$ & $4.0 \mathrm{~b}$ & - & - & - & $4.4 \mathrm{NS}$ & $3.7 \mathrm{NS}$ & $4.0 \mathrm{a}$ & $2.9 \mathrm{~b}$ \\
\hline White Wing & $3.9 \mathrm{a}$ & $4.0 \mathrm{c}$ & $4.7 \mathrm{a}$ & - & - & - & $4.3 \mathrm{NS}$ & $3.8 \mathrm{NS}$ & $3.4 \mathrm{~b}$ & $3.3 \mathrm{~b}$ \\
\hline Fiesta & $4.0 \mathrm{NS}$ & $4.6 \mathrm{NS}$ & $4.2 \mathrm{ab}$ & $4.3 \mathrm{NS}$ & $4.5 \mathrm{NS}$ & $4.3 \mathrm{NS}$ & - & - & - & - \\
\hline Florida Fantasy & $3.8 \mathrm{NS}$ & $4.3 \mathrm{NS}$ & $4.0 \mathrm{~b}$ & $4.0 \mathrm{NS}$ & $4.5 \mathrm{NS}$ & $3.8 \mathrm{NS}$ & - & - & - & - \\
\hline Hearts Desire & - & - & - & $4.0 \mathrm{NS}$ & $3.5 \mathrm{NS}$ & $3.8 \mathrm{NS}$ & $4.6 \mathrm{NS}$ & $4.0 \mathrm{NS}$ & $3.0 \mathrm{~b}$ & $4.0 \mathrm{NS}$ \\
\hline Miss Muffet & - & - & - & $4.8 \mathrm{NS}$ & $4.5 \mathrm{NS}$ & $4.2 \mathrm{NS}$ & $4.3 \mathrm{NS}$ & $4.5 \mathrm{NS}$ & $4.1 \mathrm{a}$ & $4.1 \mathrm{NS}$ \\
\hline
\end{tabular}

${ }^{2}$ Sunburn tolerance was rated on a scale of 1 to 5 , with 1 being very poor, 3 fair and acceptable, and 5 being excellent without showing any signs of leaf burns or resulted holes on leaf surfaces.

${ }^{\mathrm{y}}$ Mean separation within columns and groups by Fisher's least significant difference test at $P \leq 0.05$.

xPlants were not evaluated and data were unavailable.

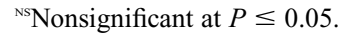

(July 2007), 'Fiesta' received a higher rating (4.1) than 'Florida Fantasy' (2.9). Plants of 'Fiesta' showed excellent sunburn tolerances in both 2007 and 2009 growing seasons, with sunburn tolerance ratings between 4.0 and 4.6 in all six evaluations (Table 5). Plants of 'Florida Fantasy' and 'White Queen' received similar sunburn tolerance ratings (3.5 to 5.0$)$.

'Hearts Desire'. This cultivar is relatively tall, with an average plant height of $46.1 \mathrm{~cm}$, $84 \%$ greater than the dwarf cultivar Miss Muffet (Table 3). Plants of 'Hearts Desire' had a similar number of leaves as 'Miss Muffet', but leaves of 'Hearts Desire' were $5.3 \mathrm{~cm}$ longer and $3.8 \mathrm{~cm}$ wider than leaves of 'Miss Muffet'. Plants of 'Hearts Desire' received good to excellent performance ratings (3.7 to 4.8) in both 2009 and 2014 growing seasons, better than or comparable to the performance ratings of 'Miss Muffet' (3.4 to 4.4) in all three evaluations in 2009 and all four evaluations in 2014 (Table 4). Plants of 'Hearts Desire' showed acceptable sunburn tolerance in both 2009 and 2014 growing seasons, with sunburn tolerance ratings between 3.0 to 4.6 in seven evaluations (Table 5). The sunburn tolerance rating of 'Hearts Desire' was significantly lower than that of 'Miss Muffet' in Oct. 2014.

\section{Recommendation}

'Cosmic Delight' is a vigorous cultivar producing taller plants with more and larger leaves than 'Gingerland' and 'White Wing'. 'Cosmic Delight' showed exceptional tuber yield potential, excellent landscape performance, and sunburn tolerance, thus suitable for landscape use in sunny and shady locations. It should also be suitable for use in large containers. Its tubers may need to be deeyed for use in small containers. 'Fiesta' is a new addition to the fancy novelty cultivar group, the 'White Queen' subgroup. 'Fiesta' sprouted earlier and produced fuller potted plants with more leaves than 'White Queen'. Also, plant quality ratings were higher than 'White Queen' in container trials, suggesting that this cultivar is highly desirable for use in pot plant production. Plants of 'Fiesta' are also expected to perform well in the landscape. 'Hearts Desire' is taller than 'Miss Muffet' and is characterized by a novel combination of foliar attributes. This new cultivar performed well in large containers and landscapes.

\section{Availability}

'Cosmic Delight', 'Hearts Desire', and 'Fiesta' were released under the names 'UFR304', 'UF-R813', and 'UF-R1012', respectively. Plant patent has been applied for these cultivars by the Florida Agricultural Experiment Station. Commercial production of these cultivars will require licensing agreements with the Florida Foundation Seed Producers, Inc., P.O. Box 309, Greenwood, FL 32443. Information on tuber availability and propagation agreements can be obtained from the Florida Foundation Seed Producers, Inc. (http://www.ffsp.net/).

\section{Literature Cited}

Baldwin, B.D., G.J. Wilfret, and B.K. Harbaugh. 2002.

'Florida White Ruffles'-A white strap-leaved caladium for small pots, hanging baskets, or sunny landscapes. HortScience 37:838840.

Bell, M.L., G.J. Wilfret, and D.A. DeVoll. 1998. Survey of caladium tuber producers for acreage of cultivars grown. Proc. Fla. State Hort. Soc. 111:32-34.

Deng, Z. and B.K. Harbaugh. 2006. 'Garden White'-A large white fancy-leaved caladium for sunny landscapes and large containers. HortScience 41:840-842.

Deng, Z., B.K. Harbaugh, R.O. Kelly, T. Seijo, and R.J. McGovern. 2005a. Pythium root rot resistance in commercial caladium cultivars. HortScience 40:549-552.

Deng, Z., B.K. Harbaugh, R.O. Kelly, T. Seijo, and R.J. McGovern. 2005b. Screening for resistance to pythium root rot among twenty-three caladium cultivars. HortTechnology 15:631634.

Deng, Z., B.K. Harbaugh, R.K. Schoellhorn, and R.C. Andrew. 2008. 2003 survey of the Florida caladium tuber production industry. Univ. of Fla./IFAS Ext. Fact Sheet, ENH 1007. 16 July 2010. <http://edis.ifas.ufl.edu/ EP258>.

Evans, M.R., G.J. Wilfret, and B.K. Harbaugh. 1992. Caladiums as potted and landscape plants. IFAS, Univ. of Fla. Agr. Ext. Serv. Circ. $1060.6 \mathrm{pp}$.

Geraldson, C.M., A.J. Overman, and J.P. Jones. 1965. Combination of high analysis fertilizers, plastic mulch and fumigation for tomato production on old agricultural land. Proc. Soil Crop Sci. Soc. Fla. 25:18-24.

Miranda, B.D. and B.K. Harbaugh. 2003. 'Florida Moonlight' - A white fancy-leaved caladium for pots and shady landscapes. HortScience 38:635-637.

Royal Horticultural Society. 1986. RHS colour chart. Royal Hort. Soc., London, UK.

SAS Institute. 2010. The SAS system for Windows. Release 9.2. SAS Inst., Cary, NC. 